\title{
Study of Gasoline Fuel blended with Composite Additive by Chemical Analysis
}

\author{
Amit R.Patil \\ PhD Scholar, Mechanical Dept., G H Raisoni College of Engineering \& Management, Pune \\ Dr. Satish. S. Ragit \\ PhD Guide, Mechanical Dept., G H Raisoni College of Engineering \& Management, Pune \\ Dr. Krishnendu Kundu \\ Scientist E, Head, Bio fuel Department, Centre for Excellence in Farm Machinery, (CSIR), \\ CMERI-Hq, Gill Road, Ludhiana- 141006
}

\begin{abstract}
The main objective of this paper was preparation of premium gasoline. Author in this prepare try to predict the effect of composite additive based on chemical analysis. Here composite additives are chemically analysed based on $\mathrm{A} / \mathrm{F}$ ration, Density and Heating value. It is observed that $\mathrm{A} / \mathrm{F}$ ration for D50E25T25 is much closed to that of pure gasoline. Also same sample show heating value is higher compare to other samples. Due to high density of toluene its mass proportion increases hence resulting in more effect on fuel sample. Overall sample D50E25T25 has chemical properties much closer to that of pure gasoline hence we can predict it will give better performance than other sample during performance and emission testing.
\end{abstract}

Keywords - Gasoline, A/F Ration, chemical properties, Composite Additives.

\section{INTRODUCTION}

One of the serious problems facing the modern technological society is the drastic increase in environmental pollution by Internal Combustion engines (IC engines). The emissions exhausted into the surroundings pollute the atmosphere and cause global warming, acid rain, smog, odor and respiratory and other health hazards. The major exhaust emissions are $\mathrm{HC}, \mathrm{CO}, \mathrm{NOx}, \mathrm{SO} 2$ and solid particles. So to increase the performance of engine the suitable additives are added to the fuel to reduce exhaust emissions. Additives are integral part of today's fuel. Together with carefully formulated base fuel composition they contribute to efficiency and long life. They are chemicals, which are added in small quantities either to enhance fuel performance, or to correct a deficiency as desired by the current legislation. They can have surprisingly large effects even when added in little amount.

\section{TYPES OF ADDITIVES}

The types of additives include oxygenates, ethers, antioxidants (stabilizers), antiknock agents, fuel dyes, metal deactivators, corrosion inhibitors. [3]

2.1.Oxygenates: They are fuels infused with oxygen. They are used to reduce the carbon monoxide emissions creating when burning fuel. Oxygenates can be based on either alcohol or ethers.

Alcohol - Methanol, Ethanol, Isopropyl alcohol, n-butanol and gasoline grade t-butanol.

Ethers - Methyl Tert-Butyl Ether (MTBE), Ethyl Tertiary Amyl Methyl Ether (TAME), Tertiary Hexyl Methyl Ether (THME).

2.2 Antioxidants: Some antioxidants are used as a stabilizer in fuel to prevent oxidation. Examples of some antioxidants used are: Butylated hydroxytoluene, 2,4-Dimethyl-6-tert-butylphenol, 2,6-Di-tert-butylphenol, Phenylene diamine, Ethylene diamine.

2.3 Antiknock Agents: These are gasoline additive that works to reduce engine knocking while trying to increase the octane rating of the fuel. The mixture of air and gas in a traditional car engine has a problem with igniting too early and when it does, it causes a knocking noise. Some of the antiknock agents are: Tetra-ethyl lead (TEL), Methylcyclopentadienyl manganese tricarbonyl (MMT), Ferrocene, Iron pentacarbonyl, Toluene, Isooctane.

\section{SELECTION OF ADDITIVES}

Oxygenated additive are used to improve combustion of fuel and reduce the emissions, antiknock additives are used to reduce knocking tendency and improve octane number, So all these additives give one or two positive effects when used individually. Instead of that if we use it as composite additive which is combination of above additives can give all positive effects which are given by them individually. So composite additive which is 
combination of one oxygenate (DMC), one antiknock (Toluene) and combination of oxygenates and antiknock (Ethanol) can reduce emissions, can reduce knocking and improve performance without showing any adverse effect.[7]

After doing literature survey following additives has been finalized

Dimethyl Carbonate (DMC): Dimethyl carbonate is an organic compound with the formula C3H6O3. It is a colorless, flammable liquid. It is classified as a carbonate ester. This compound has found use as a methylating agent and more recently as a solvent that is exempt from classification as a volatile organic compound (VOC) in the US. Dimethyl carbonate is often considered to be a green reagent. [7]

Ethanol: Commonly referred to simply as alcohol or spirits, ethanol is also called ethyl alcohol, and drinking alcohol. It is the principal type of alcohol found in alcoholic beverages, produced by the fermentation of sugars by yeasts. It is a psychoactive drug and one of the oldest recreational drugs used by humans. It can cause alcohol intoxication when consumed in sufficient quantity. Beyond being consumed, it is used as a solvent, as an antiseptic, as a fuel and as the active fluid in modern (post-mercury) thermometers. It is a volatile, flammable, colorless liquid with the structural formula $\mathrm{CH} 3 \mathrm{CH} 2 \mathrm{OH}$, often abbreviated as $\mathrm{C} 2 \mathrm{H} 5 \mathrm{OH}$ or $\mathrm{C} 2 \mathrm{H} 6 \mathrm{O}$. [9]

Toluene: Toluene is a clear, water-insoluble liquid with the typical smell of paint thinners. It is a monosubstituted benzene derivative. Toluene can be used as an octane booster in gasoline fuels used in internal combustion engines. Toluene is another in a group of fuels that have recently been used as components for jet fuel surrogate blends. Toluene is used as a jet fuel surrogate for its content of aromatic compound. As toluene has hazardous effect on living being and have limitations on its use. So, it is used in less proportion in fuel sample. [4]

\section{PREPARATION OF SAMPLE}

The finalized additives are

- Dimethyl Carbonate (DMC),

- Ethanol

- Toluene.

Table No. 4.1 Composition of Composite Additives

\begin{tabular}{llccl}
\multicolumn{1}{l}{ Sample } & \multicolumn{1}{l}{ DMC } & Ethanol & \multicolumn{1}{l}{ Toluene } \\
\hline & D50E30T20 & $50 \mathrm{ml}(50 \%)$ & $30 \mathrm{ml}(30 \%)$ & $20 \mathrm{ml}(20 \%)$ \\
& D50E40T10 & $50 \mathrm{ml}(50 \%)$ & $40 \mathrm{ml}(40 \%)$ & $10 \mathrm{ml}(10 \%)$ \\
& D50E25T25 & $50 \mathrm{ml}(50 \%)$ & $25 \mathrm{ml}(25 \%)$ & $25 \mathrm{ml}(25 \%)$ \\
$10 \%$ & D60E25T15 & $60 \mathrm{ml}(60 \%)$ & $25 \mathrm{ml}(25 \%)$ & $15 \mathrm{ml}(15 \%)$ \\
Additive & D60E20T20 & $60 \mathrm{ml}(60 \%)$ & $20 \mathrm{ml}(20 \%)$ & $20 \mathrm{ml}(20 \%)$ \\
& D60E30T10 & $60 \mathrm{ml}(60 \%)$ & $30 \mathrm{ml}(30 \%)$ & $10 \mathrm{ml}(10 \%)$ \\
& D75E15T10 & $75 \mathrm{ml}(75 \%)$ & $15 \mathrm{ml}(15 \%)$ & $10 \mathrm{ml}(10 \%)$ \\
& D75E10T15 & $75 \mathrm{ml}(75 \%)$ & $10 \mathrm{ml}(10 \%)$ & $15 \mathrm{ml}(15 \%)$
\end{tabular}

\section{CHEMICAL ANALYSIS OF FUEL SAMPLE}

The engines used in this work are designed to operate on composite additives which are a mixture of Petrol (C8H18), Dimethyl Carbonate $(\mathrm{C} 3 \mathrm{H} 6 \mathrm{O} 3)$, Ethanol $(\mathrm{C} 2 \mathrm{H} 5 \mathrm{OH})$ and Toluene $(\mathrm{C} 7 \mathrm{H} 8)$ for 10\% proportion. We calculated the stoichiometric A/ F ratio, heating value and density by finding the amount of oxygen required for complete combustion by balancing chemical reaction as explained in sample answer. First we see some physical and chemical properties of petrol and additives.[8-12]

Table 5.1 Physical properties of additives

\begin{tabular}{ccccc} 
Component & Petrol & DMC & Ethanol & Toluene \\
\hline Chemical Formula & $\mathrm{C} 8 \mathrm{H} 18$ & $\mathrm{C} 3 \mathrm{H} 6 \mathrm{O} 3$ & $\mathrm{C} 2 \mathrm{H} 5 \mathrm{OH}$ & $\mathrm{C} 7 \mathrm{H} 8$ \\
Density $\left(\mathrm{kg} / \mathrm{m}^{3}\right)$ & 0.700 & 1.070 & 0.789 & 0.866 \\
Molar mass & 114 & 90 & 46 & 92.13 \\
$\begin{array}{c}\text { Heating value } \\
(\mathrm{KJ} / \mathrm{kg})\end{array}$ & 44000 & 15780 & 26900 & 42420
\end{tabular}




\subsection{SAMPLE CALCULATION FOR D50E30T20:}

Table 5.2 Chemical properties of fuel sample D50E30T20

\begin{tabular}{|c|c|c|c|c|}
\hline D50E30T20 & Petrol & $\mathbf{D}$ & $\mathbf{E}$ & $\mathbf{T}$ \\
\hline$\%$ Fuel sample & $90 \%(900 \mathrm{ml})$ & & $10 \%(100 \mathrm{ml})$ & \\
\hline Volumetric Fraction (for 1lit) (V) (ml) & 900 & 50 & 30 & 20 \\
\hline $\operatorname{Mass}(\mathrm{m})=\mathrm{V}^{*} \operatorname{den} \operatorname{sity}(\mathrm{gm})$ & 630 & 53.5 & 23.67 & 17.32 \\
\hline Mol mass (M) (gm/mol) & 114 & 90 & 46 & 92.13 \\
\hline $\operatorname{Mol}$ number $(\mathrm{N})=\mathrm{m} / \mathrm{M}$ (moles) & $\mathrm{N} 1=5.52$ & $\mathrm{~N} 2=0.594$ & $\mathrm{~N} 3=0.515$ & $\mathrm{~N} 4=0.188$ \\
\hline
\end{tabular}

\subsubsection{AIR FUEL RATIO FOR FUEL SAMPLE D50E30T20:}

Chemical Reaction for complete combustion of fuel sample

$$
\begin{aligned}
& \mathrm{N} 1(\mathrm{C} 8 \mathrm{H} 18)+\mathrm{N} 2(\mathrm{C} 3 \mathrm{H} 6 \mathrm{O} 3)+\mathrm{N} 3(\mathrm{C} 2 \mathrm{H} 5 \mathrm{OH})+\mathrm{N} 4(\mathrm{C} 7 \mathrm{H} 8)+\mathrm{x}(0.21 \mathrm{O} 2+0.79 \mathrm{~N} 2) \rightarrow \\
& {[8 \mathrm{~N} 1+3 \mathrm{~N} 2+2 \mathrm{~N} 3+7 \mathrm{~N} 4] \mathrm{CO} 2+[9 \mathrm{~N} 1+3 \mathrm{~N} 2+3 \mathrm{~N} 3+4 \mathrm{~N} 4] \mathrm{H} 2 \mathrm{O}+0.79 \mathrm{~N} 2} \\
& x=[12.5 \mathrm{~N} 1+3 \mathrm{~N} 2+3 \mathrm{~N} 3+9 \mathrm{~N} 4] / 0.21
\end{aligned}
$$

From Table 5.2,

$\mathrm{N} 1=5.520, \mathrm{~N} 2=0.594, \mathrm{~N} 3=0.515, \mathrm{~N} 4=0.188$,

Putting in above eq., we get

$\mathrm{x}=352.47$ Moles.

Mass of air $(\mathrm{ma})=x(0.2102+0.79 \mathrm{~N} 2)$

$=352.47 *(0.21 * 32+0.79 * 28)$

$=10165.2348 \mathrm{gm}$

Mass of Fuel $(\mathrm{mf})=\mathrm{m} 1+\mathrm{m} 2+\mathrm{m} 3+\mathrm{m} 4=724.49 \mathrm{gm}$

A $/$ F Ratio $=\mathrm{ma} / \mathrm{mf}=\mathbf{1 4 . 0 3 0}$

\subsubsection{HEATING VALUE OF FUEL SAMPLE D50E30T20:}

$$
\begin{aligned}
& \mathrm{mQ}_{\text {Sample }}=(\mathrm{mQ}) \text { Petrol }+(\mathrm{mQ}) \mathrm{DMC}+(\mathrm{mQ}) \text { Ethanol }+(\mathrm{mQ}) \text { Toluene }(\mathrm{KJ}) \\
& \mathrm{Q}_{\text {sample }}=\mathrm{Q} \text { sample } / \mathrm{m} \text { sample }(\mathrm{KJ} / \mathrm{kg}) \\
& \mathrm{m}^{*} \mathrm{Q}_{\mathrm{D} 50 \mathrm{E} 30 \mathrm{~T} 20}=630 *(44000 / 1000)+3.5 *(15780 / 1000)+23.67 *(26900 / 1000)+17.32 *(42420 / 1000) . \\
& \mathrm{mQ}_{\text {D50Е30T20 }}=29935.6674 \mathrm{KJ} \\
& \mathrm{Q}_{\text {D50Е30T20 }}=29935.6674 / 0.7245=41319.07 \mathrm{KJ} / \mathrm{kg}
\end{aligned}
$$

\subsubsection{DENSITY OF FUEL SAMPLE D50E30T20:}

$$
\begin{aligned}
& \rho \text { sample }=0.9 * \mathrm{M} 1+0.1(\mathrm{~V} 1 * \mathrm{M} 2+\mathrm{V} 2 * \mathrm{M} 3+\mathrm{V} 3 * \mathrm{M} 4) \\
& \text { Where, }(\mathrm{V} 1, \mathrm{~V} 2, \mathrm{~V} 3 \text { : Proportion of additives in sample }) \\
& \rho=\text { density of Sample } \\
& \mathrm{V}=\mathrm{V} \text { ol. Proportion in Sample. } \\
& \rho_{\mathrm{D} 50 \mathrm{E} 30 \mathrm{~T} 20}=0.9 * 0.700+0.1(0.5 * 1.07+0.30 * 0.789+0.20 * 0.866) \\
& \rho_{\mathrm{D} 50 \mathrm{E} 30 \mathrm{~T} 20}=0.7245 \mathrm{~kg} / \mathrm{m}^{3} .
\end{aligned}
$$


Similarly A/F Ratio, heating value and density calculation for other sample has been done and result has been tabulated in Table 6.1

\section{RESULTS}

Using above calculation methods we found out the above parameters for all the additives with varying $\%$ of additives in petrol. The results are tabulated as below

\begin{tabular}{|c|c|c|c|}
\hline Sample & A/F Ratio & $\begin{array}{l}\text { Heating value } \\
\qquad(\mathrm{KJ} / \mathbf{k g})\end{array}$ & $\begin{array}{l}\text { Density } \\
\left(\mathrm{kg} / \mathrm{m}^{3}\right)\end{array}$ \\
\hline Pure Petrol & 14.700 & 44000 & 0.7000 \\
\hline D50E30T20 & 14.030 & 41319.07 & 0.7245 \\
\hline D50E40T10 & 13.980 & 41149.27 & 0.7237 \\
\hline D50E25T25 & 14.055 & 41404.69 & 0.7248 \\
\hline D60E25T15 & 13.900 & 41015.40 & 0.7269 \\
\hline D60E20T20 & 13.907 & 41095.25 & 0.7273 \\
\hline D60E30T10 & 13.899 & 40930.39 & 0.7265 \\
\hline D75E15T10 & 13.775 & 40605.22 & 0.7307 \\
\hline D75E10T15 & 13.798 & 40689.92 & 0.7311 \\
\hline
\end{tabular}

6.1 SAMPLE VS A/F RATION:

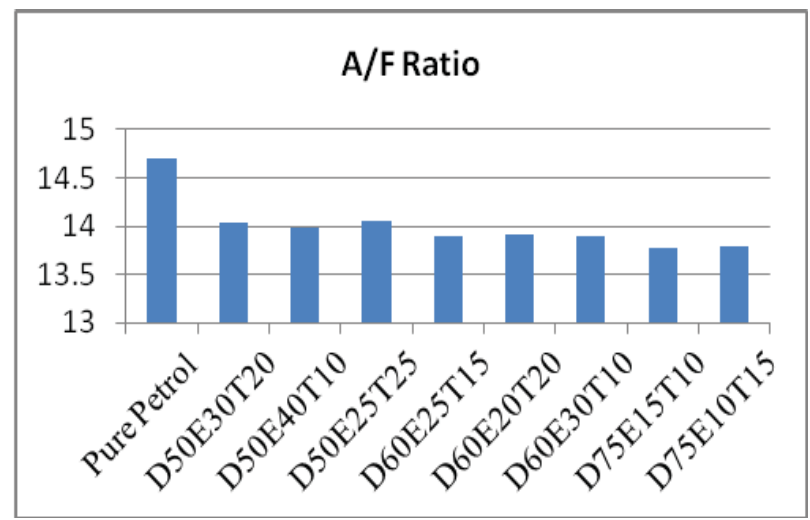

6.2 SAMPLE vs. density: 


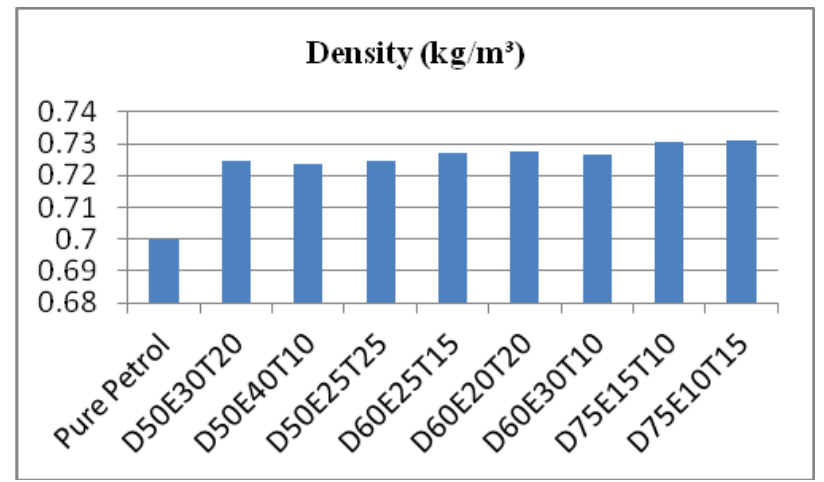

6.3 SAMPLE VS. HEATING VALUE:

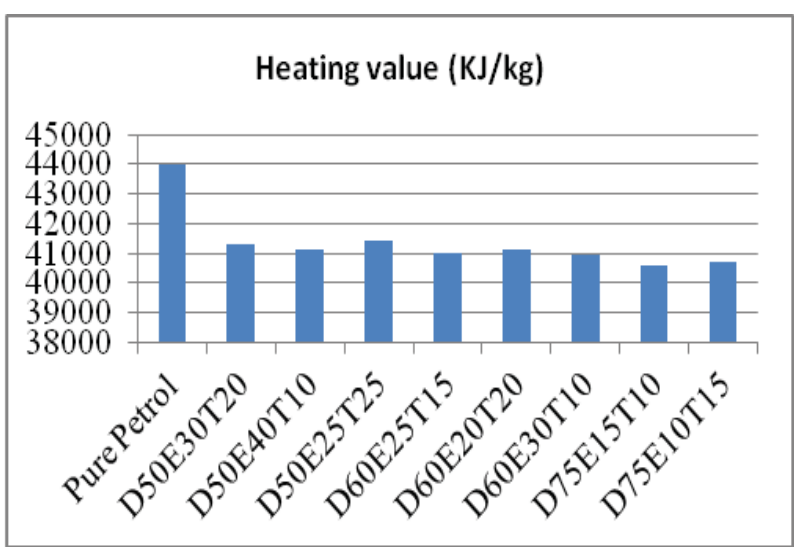

VII. CONCLUSION

Thus from the study carried out in the paper we conclude that as the amount of additive in a sample with petrol increases, it has significant effects on the properties of the sample. As seen from the table \& pie chart above, as the percentage of additive increases, the A/F ratio, heating value 7 density of the sample decreases. Thus $5 \% \mathrm{DMC}$ in petrol has $\mathrm{A} / \mathrm{F}$ ratio of 14.28 , density of $0.634 \mathrm{~g} / \mathrm{cc} \&$ heating value of $41.74 \mathrm{MJ} / \mathrm{kg}$ while $10 \% \mathrm{DMC}$ has $\mathrm{A} / \mathrm{F}$ ratio of 13.92 , density of $0.577 \&$ heating value of $39.57 \mathrm{MJ} / \mathrm{kg}$. This further confirms our conclusion.

\section{REFERENCES}

[1] D.B. Sivakumar, M. Arulmozhi, T. Senthil Kumar, "Performance \& emission of S.I. Engine with oxygenated fuel". IEEE-International Conference On Advances In Engineering, Science And Management (1CAESM -2012) March 30, 31, 2012, pp.117-121.

[2] S.Babazadeh Shayan, F.Ommi, S.M.Seyedpour, M.Alizade, "Influence of oxygenates blending with gasoline on fuel properties". International Journal of Energy \& Technology, 3 (19) (2011), pp 1-6.

[3] A R Patil, S G Taji, "Effect of oxygenated fuel additive on diesel engine performance and emission: A review, IOSR Journal of Mechanical and Civil Engineering (IOSR-JMCE)"

[4] C. Anish Raman, Dr. K. Varatharajan, P.Abinesh, Dr. N. Venkatachalapathi, "Analysis of MTBE as an Oxygenate Additive to Gasoline". Int. Journal of Engineering Research and Applications 2014. Vol. 4, Issue 3( Version 1), March 2014, pp.712-718.

[5] D. Balaji, Dr. P. Govindarajan, J. Venkatesan, "Influence of isobutanol blend in spark ignition engine performance and emissions operated with gasoline and ethanol". International Journal of Engineering Science and Technology, Vol. 2(7), 2010, pp. 2859-2868.

[6] Lan-bin Wen, Chen-Ying Xin, Shyue-Cheng Yang, "The effect of adding dimethyl carbonate (DMC) and ethanol to unleaded gasoline on exhaust emission", Applied Energy 87 (2010), pp 115-121.

[7] Mr Amit R Patil, SG Taji, Need of composite additives for diesel fuel: A review, International Journal of Engineering Research and Technology, Vol2, Issue11, Nov 2013

[8] Mustafa Koç, Yakup Sekmen, Tolga Topgu, Hu seyin Serdar Yu cesu, "The effects of ethanol-unleaded gasoline blends on engine performance and exhaust emissions in a spark-ignition engine", Renewable Energy 34 (2009) pp. 2101-2106.

[9] Pamela M. Franklin, Catherine P. Koshland, Donald Lucas, Robert F. Sawyer, "Evaluation of combustion by-products of MTBE as a component of reformulated gasoline", Chemosphere 42 (2001), pp.861-872.

[10] Technology Insight Report- Fuel Additives, "Patent iNSIGHT Pro ${ }^{\text {TM }}$ C 2010 Gridlogics".

[11] Prof Amit R.Patil, Prof. R. N. Yerrawar, Mr Shrinath A.Nigade, Mr. Onkar B.Chavan, Mr. Hitendra S.Rathod, Mr. Bhushan K.Hiran, “ Literature Review on need of Composite Additives for S.I Engine”, International Journal For Research \& Development in Technology (IJRDT) Volume: 2, Issue: 4, Oct -2014 ISSN (Online):- 2349-3585.

[12] Shyam kumar Menon, "Performance Scaling and measurements in small internal combustion engine", $\mathrm{PhD}$ thesis,2006. 